\title{
Factors Affecting COVID 19 - related CSR Activities of Slovak Companies
}

\author{
Jana Kozakova ${ }^{1 *}$ \\ ${ }^{1}$ Slovak University of Agriculture in Nitra, Faculty of Economics and Management, Department of \\ Management, Trieda A. Hlinku 2, 94976 Nitra, Slovakia
}

\begin{abstract}
.
Research background: The socio-economic consequences of Covid-19 pandemic are visible through changes in the business sector. Companies took various steps to their elimination primarily by protection of employees which went beyond the ordinary legal norms. Therefore, these activities can be described as socially responsible. In Slovakia, CSR is the domain of multinational companies which transfer modern managerial tools to their foreign branches as it is in case of pandemic-related activities.

Purpose of the article: Study examined 191 Slovak subsidiaries of foreign multinationals with the purpose to describe factors (legal form, residence in Slovakia, year of establishment, share of foreign ownership, woman in the board) which affecting their COVID-19 related CSR activities (cleanliness, protective equipment, social distancing, prevention, local community, extra benefits).

Methods: Procedure based on the Shapiro Wilk test of normality which verify a normal distribution of sample. Next the Durbin-Watson test confirmed no autocorrelation between set variables. After the KruskalWallis nonparametric test was applied with the assumption of statistically significant differences between variables and subsequent Bonferroni post hoc test found relationship between them.

Findings \& Value added: Study shows the level of emphasis companies place on CSR activities related to COVID-19. Analysis enlightens the differences in this emphasis in case of providing protective equipment between companies of various capital structure. Also, there were differences in prevention between companies of various legal form and predominant gender in the board. Lastly the difference was found in providing extra benefits in companies of differ year of establishment.
\end{abstract}

Keywords: COVID-19; corporate social responsibility; multinational enterprises; Slovakia

JEL Classification: $I 18 ; D 89 ; M 16 ; O 35$

\footnotetext{
*Corresponding author: jana.kozakova@uniag.sk
} 


\section{Introduction}

The COVID-19 pandemic affected the lives of individuals and organizations in several ways. As a result, economic goals had to give way to humanitarian ones and the business sector very quickly began to lose revenue due to measures to spread the pandemic in most areas (Nalband and Kelabi, 2014). In addition, the costs associated with ensuring the protection of the health and life of employees have increased significantly for companies, which has had a further negative impact on their profits. Shortly on, the subjects had to deal with a decreased income and raised expenditures at the same time (Meyer et al., 2021). The first microeconomic effects of the pandemic were raised operating costs on the disinfect premises, hygiene items and protective equipment (Mulugeta et al., 2021) such as drapes, gloves, respirators, and protective clothing. Some companies have gone even further by purchasing thermal sensors, disinfection dispensers, germicidal radiators and other technical equipment ensuring increased hygiene. The most visible managerial change was the transfer to the working from home (Beck and Hensher, 2021) for all employees who were allowed to do so by the nature of their work which significantly affected the operations of organizations.

Trendsetters of many managerial novelties are multinational corporations which cross country demesne of operations is ensured by the transfer of managerial approaches from countries where their application has proven itself (usually home country) to other countries where the company operates (host countries) (Filatotchev and Stahl, 2015). This transfer is of special importance in emerging markets, as for example Slovak market, where managerial novelties slowly penetrated thorough MNCs (Multinational Corporations) after 1991 while restored approaches of individual entrepreneurship and market competition. Corporate social responsibility (CSR) being one of those tools (Čarnogurský et al, 2015). CSR is understood as the way organizations integrate social, environmental, and economic concerns into their values, culture, decision making, strategy and operations in a transparent and accountable manner and thereby prove better practices, create wealth, and improve society (Nalband and Kelabi, 2014). However, there no officially agreed definition of CSR nor activities it includes. One of the rare definitions of regulatory bodies is the one by (EC, 2006) which stated that CSR is a concept whereby companies integrate social and environmental concerns in their business operations and in their interaction with their stakeholders on a voluntary basis. EC believes that it is important for the sustainability, competitiveness, and innovation of EU (European Union) enterprises and the economy since it brings benefits for risk management, cost savings, access to capital, customer relationships, and human resource management. This general consensus on the balance of economic, environmental, and social imperatives is known as Triple-Bottom-Line-Approach (Low, 2016) which consider that the company is a part of a broad relationship system, and its prosperity depends on the state of the society in which it operates and on the attitudes of the segments involved towards it. The concept presents individual areas of interest referred to as three 'P': Profit (economic), People (social), Planet (environmental) (Slaper and Hall, 2011) designed to show that economic interests may not be at odds with social and environmental ones, but they exist in parallel and cooperation which creates a competitive advantage.

Research gap: Despite the problem of COVID-19 occurs just few years ago, it skyrockets all areas of public/private life and the business world and the field of scientific research too. However, activities beyond the law requirements companies incorporated regarding COVID19 - related situation examined only once (Popkova et al., 2021). Considerable part of current research aiming at travelling and tourism under COVID-19 circumstances also from CSR point of view (e.g.: Shin et al., 2021). Other CSR research is limited to the donation of corporate leaders (Kim and $\mathrm{Ji}, 2021$ ) and connection between CSR and economic performance (Wapstra et al., 2003; Bae et al., 2021). As far as we know, there is no COVID19 related research touching the topic of CSR in Slovakia. Our paper fills this gap and starts with the description of basic socially responsible activities related with COVID-19 situation 
on the sample of 191 Slovak companies connected with foreign multinationals since they were considered as pioneers of CSR activities in emerging markets (Mladenović et al., 2017). Paper analyses the differences in the emphasis which Slovak subsidiaries place on COVID19 related CSR activities in following design - Structure of paper: the problem and its state of research is described in introduction part; the design of study and hypothesis it implicates are compiled in methodology part; next, obtained results are displayed in connection with the outcomes of other authors; finally, the part of conclusions is included.

\section{Methodology}

The goal of this study is to analyse the differences in the emphasis which subsidiaries of multinational enterprises in Slovakia place on COVID-19 related socially responsible activities.

Data Collection: The research was conducted in the form of interview (Gillham, 2000) using the Google forms online questionnaire (Rayhan, 2013) filled by trained interviewers. For participation in the study exclusively companies registered in the Commercial Register of the Slovak Republic which are connect with the foreign multinational companies were addressed based on stratified randomization (Kim and Shin, 2014). Out of 300 addressed entities, 200 were cooperated. Therefore, the response rate of $85 \%$ was calculated. Following data adjustment (Wapstra et al., 2003) narrowed sample to 191 examined companies.

Design of Study: Presented outcomes are part of the extensive study aimed at various aspects of international management and entrepreneurship of foreign multinationals in Slovakia. In this paper, only the part of sorting questions and COVID-19 related CSR activities were used. Initially, the set of fifteen sorting characteristics were tested: Legal form, Residence in Slovakia, Year of establishment, Number of board members, Share of foreign ownership; Area of operation, Industry, Number of employees, Type of investment of mother company, Form of entry Slovak market, Registered office of the parent company, Number of host countries, Number of affiliates in Slovakia, Gender of director, Women in the board. Statistical significances were found only in case of five (Table 4) which were chose as factors for this study. Table 1 presents these factors F1-F5 and the frequency of occurrence of individual answers on questions related to them (characteristics of research sample).

Table 1 Design of questionnaire factors

\begin{tabular}{|c|c|c|}
\hline Code & Title & Options and its frequencies - characteristic of research sample \\
\hline F1 & Legal form & $\begin{array}{l}\text { 1-Joint Stock Company (54); } 2 \text {-Limited Liability Company (135); 3- } \\
\text { Public Company (2); } 4 \text { - Limited Partnership (0); } 5 \text { - Cooperative (0) }\end{array}$ \\
\hline $\mathrm{F} 2$ & $\begin{array}{l}\text { Residence in } \\
\text { Slovakia }\end{array}$ & $\begin{array}{l}\text { 1- BA - Bratislava Region (80); 2- TR - Trnava Region (22); 3- TT - } \\
\text { Trenčín Region (17); 4- NR - Nitra Region (49); 5- ZA - Žilina Region } \\
\text { (9); 6- BB - Banská Bystrica Region (6); 7- PE - Prešov Region (5); 8- } \\
\text { KE - Košice Region (3) }\end{array}$ \\
\hline F3 & $\begin{array}{l}\text { Year of } \\
\text { establishment }\end{array}$ & $\begin{array}{l}\text { 1- 1990-1995 (68); 2- 1996-2000 (34); 3- 2001-2005 (38); 4- 2006-2010 } \\
\text { (22); 5- 2011-2015 (16); 6- 2016-2020 (13) }\end{array}$ \\
\hline F4 & $\begin{array}{l}\text { Foreign } \\
\text { ownership }\end{array}$ & $1-$ Yes (142); 2- No (49) \\
\hline F5 & $\begin{array}{l}\text { Woman in } \\
\text { the board }\end{array}$ & $\begin{array}{l}\text { 1-Only women (7); } 2 \text { - Only men (116); } 3 \text { - Mostly men (32); 4- Mostly } \\
\text { women (36) }\end{array}$ \\
\hline
\end{tabular}

Source: own processing

The occurrence of individual factors is not balanced, but it corresponds to the composition of the business sector in Slovakia. The second part of used outcomes was related to CSR activities which companies conduct as a reaction on COVID-19. Since there is no general agreement on which COVID-19 related activities can be consider as socially responsible we 
build a list of these based on general definition of CSR which describe them as activities which companies do beyond the law (Kim and Ji, 2021; Popkova et al., 2021) and which can at the same time fit to economic, environmental, or social category (Low, 2016; Slaper and Hall, 2011). Regarding this, all fifteen tested variables and therefore choose variables E1-E6 were identified. In the study representatives of monitored companies were asked to rate the emphasis which company place on these COVID-19 related CSR activities (Table 2) which can be divide into categories set as variables E1-E6 which frequencies displayed Graph1.

Table 2 Design of questionnaire/variables

\begin{tabular}{|l|l|l|}
\hline Code & Title & $\begin{array}{l}\text { Research question: How strong emphasis does the company place on } \\
\text { CSR activities related to COVID-19? }\end{array}$ \\
\hline V1 & Cleanliness & Disinfection and cleanliness of areas \\
\hline V2 & $\begin{array}{l}\text { Protective } \\
\text { Equipment }\end{array}$ & $\begin{array}{l}\text { Equipping employees with protective aids (drape, gloves, respirator } \\
\text { etc.) }\end{array}$ \\
\hline V3 & $\begin{array}{l}\text { Social } \\
\text { Distancing }\end{array}$ & $\begin{array}{l}\text { Elimination of social contacts in the workplace (Home Office, separate } \\
\text { shifts, changes in schedules) }\end{array}$ \\
\hline V4 & Prevention & $\begin{array}{l}\text { Increased expenses for prevention (testing at the employer's expense, } \\
\text { reimbursement of nutritional supplements, etc.) }\end{array}$ \\
\hline V5 & $\begin{array}{l}\text { Local } \\
\text { Community }\end{array}$ & $\begin{array}{l}\text { Helping the public and the local community (sponsorship, participation } \\
\text { in testing, vaccine research, etc.) }\end{array}$ \\
\hline V6 & Extra Benefits & $\begin{array}{l}\text { Extra employee benefits (possibility to complete voluntary quarantine } \\
\text { with income compensation, etc.) }\end{array}$ \\
\hline
\end{tabular}

Source: own processing

The answers on COVID-19 related questions were designed as Likert scale with following options: 1- Nothing beyond law; 2- Minimum above ordinary; 3- Ordinary; 4Slightly above ordinary; 5- Strongly above ordinary. To analyse the differences in the emphasis which monitored companies place on COVID-19 related CSR activities the general hypothesis $\mathrm{H} 0$ and the set of alternative hypothesis Ha were set:

- H0: There is no difference between monitored companies in the emphasis they place on COVID-19 related CSR activities.

- Ha: There is a difference between monitored companies in the emphasis they place on COVID-19 related CSR activities.

This alternative hypothesis was extended to the set of derivate specific hypotheses (Table 3).

Table 3 Alternative hypothesis derivate from $\mathrm{Ha}$

\begin{tabular}{|c|c|c|c|c|}
\hline No & \multirow{6}{*}{$\begin{array}{l}\text { There is a } \\
\text { statistically } \\
\text { significant } \\
\text { difference } \\
\text { between } \\
\text { monitored } \\
\text { companies of } \\
\text { various... }\end{array}$} & Factors & \multirow{6}{*}{$\begin{array}{l}\ldots \text { in the } \\
\text { emphasis } \\
\text { they place } \\
\text { on COVID- } \\
19 \text { related } \\
\text { CSR } \\
\text { activities... }\end{array}$} & Variables \\
\hline H1 & & F1 Legal form & & V1 Cleanliness \\
\hline $\mathrm{H} 2$ & & F2 Residence in Slovakia & & V2 Protective Equipment \\
\hline $\mathrm{H} 3$ & & F3 Year of establishment & & V3 Social Distancing \\
\hline $\mathrm{H} 4$ & & F4 Foreign ownership & & V4 Prevention \\
\hline $\mathrm{H} 5$ & & F5 Woman in the board & & V5 Local Community \\
\hline
\end{tabular}

Source: own processing

Computed $p$-value lower than the significance level alpha $=0.05$, indicates to reject the null hypothesis $\mathrm{H} 0$, and accept the alternative hypothesis Ha and vice versa.

Procedure: Initially, the Shapiro Wilk test of normality (Shapiro and Francia, 1972) was used with the outcome of Sig. $=0.000$ for all factors F1-F5 which confirmed that data are not normally distributed for each level of independent variables. Next, the Durbin - Watson test (Watson and Durbin, 1951) show outcomes between 1.5 and 2.5 for all factors F1-F5 and 
confirmed no autocorrelation between them. Afterward, the Kruskal-Wallis nonparametric test (Kruskal and Wallis, 1952) was applied with the assumption of statistically significant differences between F1-F5 on dependent variables E1-E6. Found significant differences were subsequently examined by Bonferroni post hoc test (Lee and Lee, 2018) with the assumption that the data are a random sample from a normal population. Post hoc analysis was based on estimated marginal means with the mean difference significant at the 0.05 level and using $\mathrm{P}$ value adjusted for Bonferroni correction. For the statistical analysis and computing of data frequencies, the Software IBM SPSS Statistics Subscription 1.0.0.1447 was used.

\section{Results and discussion}

COVID-19 related socially responsible activities of monitored companies were closely examined in six categories (Table 2) reflecting afford which extended law requirements in favour of company's stakeholders (employees, local community, etc.). These were included in variables V1-V6 and ranked on Likert scale from 1 to 5. Out of these (Figure 1) monitored companies placed the strongest emphasis on cleanliness and protective equipment for employees. On the other side, the weakest emphasis was placed on activities in benefit of local community and extra benefits for employees. We believe that the reason of this weak involvement is in fact that research was conducted in the situation of actual lockdown at the time when companies aimed to stabilizing of acute situation and focus on elimination of post COVID problems during season of better epidemiological situation.

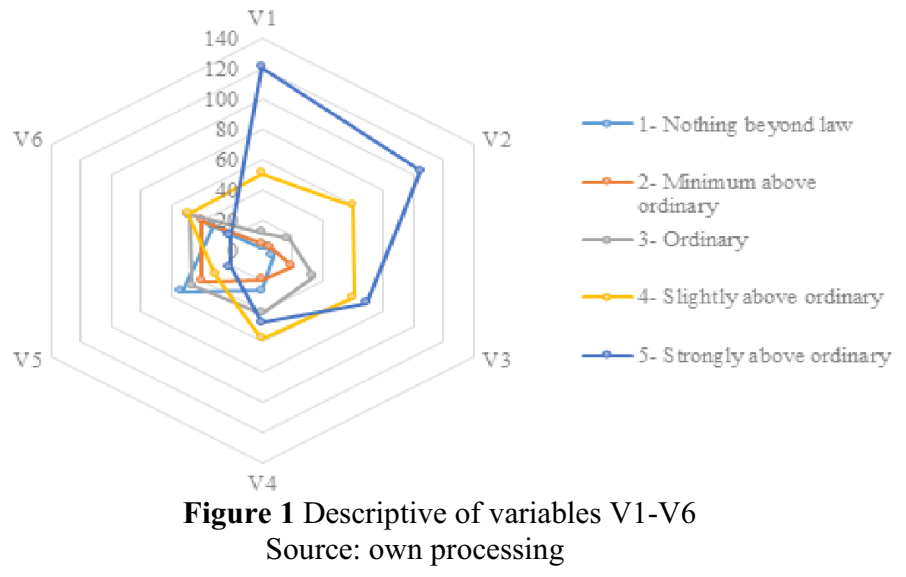

COVID-19 related CSR activities (V1-V6) were examined by Kruskal-Wallis test according the set of 15 factors with the result of just five factors (F1-F5) considered as statistically significant (Table 4). In case of these we can reject the null hypothesis and adopt the alternative hypotheses (H1-H5).

Table 4 Kruskal-Wallis according to factors F1-F5

\begin{tabular}{|l|l|c|c|c|r|r|r|}
\hline & Factor/Variable & V1 & V2 & \multicolumn{1}{l|}{ V3 } & \multicolumn{1}{l|}{ V4 } & \multicolumn{1}{l|}{ V5 } & \multicolumn{1}{l|}{ V6 } \\
\hline F1 & Legal form & 0.286 & 0.089 & 0.215 & $\underline{0.026}$ & 0.055 & 0.119 \\
\hline F2 & Residence in Slovakia & 0.806 & 0.284 & 0.843 & 0.213 & $\underline{0.030}$ & 0.080 \\
\hline F3 & Year of establishment & 0.433 & 0.469 & 0.363 & 0.475 & 0.225 & $\underline{0.049}$ \\
\hline F4 & Share of foreign ownership & 0.293 & $\underline{0.025}$ & 0.332 & 0.757 & 0.432 & 0.989 \\
\hline F5 & Woman in the board & 0.188 & 0.055 & 0.359 & $\underline{0.005}$ & 0.160 & 0.092 \\
\hline
\end{tabular}

Source: own processing 
Alternative hypothesis $\mathrm{H} 1$ was accepted for variable (V4) prevention with $\mathrm{p}=0.026$ which shows statistically significant difference between monitored companies of various (F1) legal form in the emphasis they place on COVID-19 related CSR activity "prevention" in the form of increased expenses on testing at the employer's expense or reimbursement of nutritional supplements. Subsequent Bonferroni pairwise comparison found this difference just between Joint Stock Companies (JSC) and Limited Liability Companies (LLC) (Mean Difference = 0.511; Sig. adjusted for multiple comparisons $=0.049$ ). In fact, no CSR activities realize just $7.41 \%$ of JSCs and $16.30 \%$ of LLCs. Enormous difference was found also in case of strong CSR implementation since just $35.19 \%$ of JSCs confirmed strong involvement beyond ordinary, while just $20 \%$ LLCs doing so (Figure 2). Stronger involvement of Joint Stock Companies in prevention of COVID-19 can be explained by the fact that JSCs must realize activities in regard of building goodwill and remain interest of shareholders for which CSR is ideal tool. The ones aimed at direct elimination of COVID-19 impact appear to be ideal.

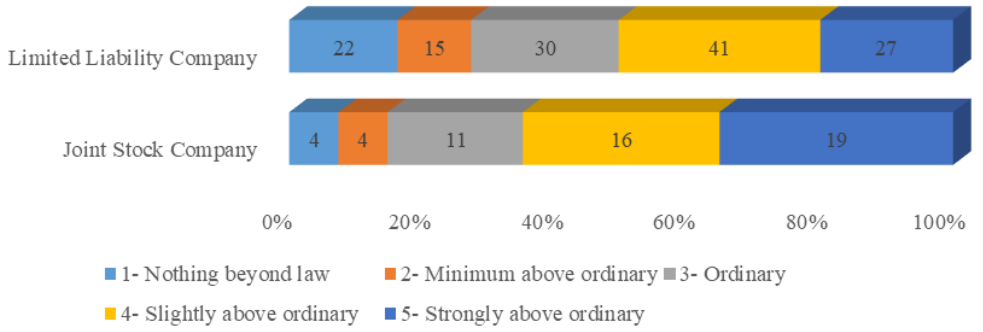

Figure 2 Descriptive of factors identified as different by Bonferroni V4/F1 pairwise comparison

Source: own processing

The second alternative hypothesis $\mathrm{H} 2$ was accepted for variable (V5) local community with $\mathrm{p}=0.030$ which can be described as statistically significant difference between monitored companies of various (F2) Residence in Slovakia in the emphasis they place on helping the public and the local community with the COVID-19 related situation in the form of sponsorship, participation in testing, vaccine research, etc. Subsequent Bonferroni pairwise comparison found this difference just between BA - Bratislava region and NR- Nitra region (Mean Difference $=0.721$; Sig. adjusted for multiple comparisons $=0.043$ ) while no CSR activities towards local community realize $42.86 \%$ companies headquartered in Nitra region and only $18.75 \%$ of companies headquartered in Bratislava. Also, strong emphasis on CSR activities shows $15.00 \%$ of BA companies and just $2.04 \%$ of NR companies (Figure 3). Stronger involvement of BA companies when comparing with NR ones can be described by overall higher development of managerial approaches and widespread use of innovative management tools in the Bratislava region due to the fact that there is the highest concentration of strong and developed foreign multinational companies in Slovakia.

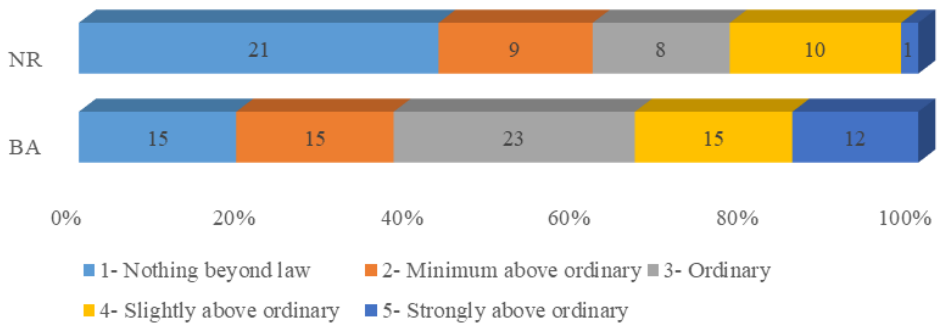

Figure 3 Descriptive of factors identified as different by Bonfferoni V5/F2 pairwise comparison

Source: own processing 
Next alternative hypothesis H3 was accepted for variable (V6) Extra Benefits with $\mathrm{p}=0.049$ which indicates statistically significant difference between monitored companies of various (F3) Year of Establishment in the emphasis they place on extra employee benefits related with elimination of COVID-19 incidence such as for example possibility to complete voluntary quarantine with income compensation. Ongoing Bonferroni pairwise comparison found this difference just between companies established between 1996-2000 and those established between 2001-2005 (Mean Difference $=1.505$ - An estimate of the modified population marginal mean; Sig. adjusted for multiple comparisons $=0.009$ ) while companies established later are involved less than those established before 2000 since they outnumber in every part of the scale (Figure 4), except no involvement. This can be explained by the fact that previously established companies have more entrenched socially responsible activities, their application has a longer history and is therefore built on stronger foundations.

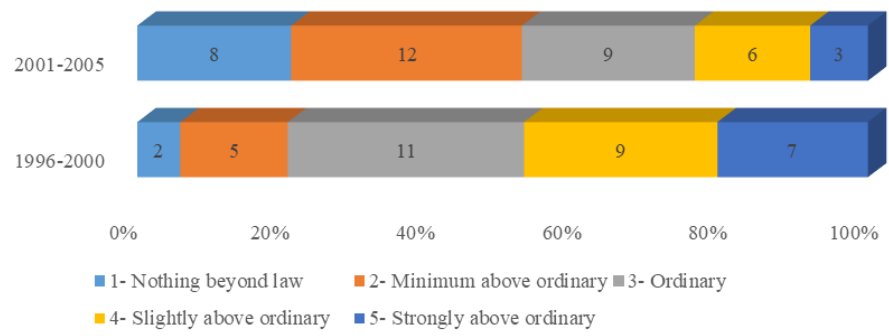

Figure 4 Descriptive of factors identified as different by Bonferroni V6/F3 pairwise comparison

Source: own processing

As the next variable, the (F4) Share of foreign ownership was examined with the outcome of statistical significance. Therefore, we can accept alternative hypothesis $\mathrm{H} 4$ with $\mathrm{p}=0.025$ and statistically significant difference between monitored companies with and without foreign ownership in their ownership structure in the emphasis they place on equipping employees with protective aids (drape, gloves, respirator etc.) in regard of elimination of COVID-19 incidence. Subsequent Bonferroni pairwise comparison was not necessary since only two options were available (Figure 5). We can confirm stronger involvement in selected CSR activity in companies with foreign ownership which we believe relates to the stronger transmission of organizational culture of mother company when it has share in daughter's financial structure since higher involvement in CSR is typical for advanced companies with stronger organizational culture.

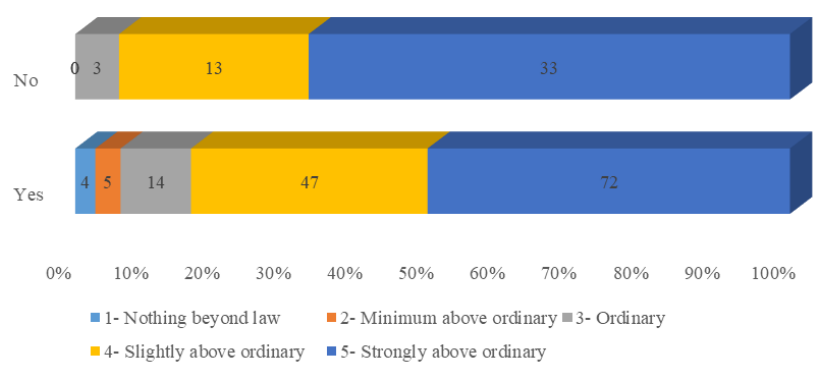

Figure 5 Descriptive of factors identified as different by Bonferroni V2/F4 pairwise comparison Source: own processing 
Last factor identified as significant was (F5) Woman in the board, with $\mathrm{p}=0.005$ which indicates statistically significant difference between monitored companies of various share of woman in their board in the emphasis they place on prevention connect with the COVID19. This prevention includes increased expenses on testing at the employer's expense, or reimbursement of nutritional supplements for employees. According to this we can accept alternative hypothesis H5. Bonferroni pairwise comparison found difference between companies which has only woman in their board and which has mostly men in it (Mean Difference $=0,753$; Sig. adjusted for multiple comparisons $=0.16$ ). Companies with only woman in the board are slightly stronger involved in described CSR activity which can be explained by overall higher involvement of companies with predominant woman leaders in corporate social responsibility.

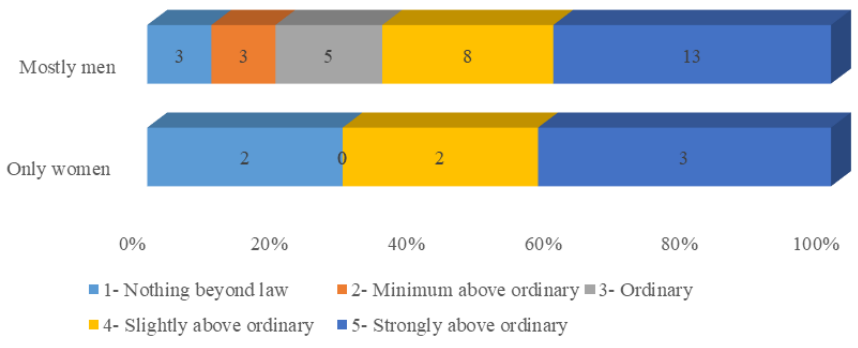

Figure 6 Descriptive of factors identified as different by Bonferroni V4/F5 pairwise comparison

Source: own processing

Limitations: To be honest, the fact that our research does not contain cultural context must be mentioned. The truthful and comprehensive research in the field of CSR realised on the companies connect with multinationals should consider cultural differences between home and host country which can affect their socially responsible approach [11]. Therefore, we strongly recommend for future research to be cultural sensitive when designing methodology of the research and build it with the emphasis on cultural dimensions [15]. Also, the extent of presented paper does not allow us to display all obtained results in the suitable visual form. Therefore, the results of Kruskal-Wallis analyses were shortened to one table (Table 1), results of post hoc Bonferroni comparison were just mentioned in the text and contingency tables were transformed to pictures displaying just results of Bonferroni.

\section{Conclusion}

Arrangements related to the effort to stop the spread of the COVID-19 epidemic in Slovakia have affected business entities in many aspects. The primary effort was to protect the health of employees. Therefore, employers had to provide several protective and preventive measures that were not required by law at the time. It was therefore a socially responsible corporate behaviour in the true sense of the word. Our study conducted in the form of online questionnaire research on the sample of 191 Slovak companies connect with foreign multinationals aim at the emphasis which subsidiaries place on COVID-19 directly related socially responsible activities (cleanliness, protective equipment, social distancing, prevention, local community, and extra benefits). These variables were tested in connection with fifteen factors (sorting characteristics of monitored companies) out of which just five were identified as statistically significant (legal form, residence in Slovakia, year of establishment, foreign ownership, and woman in the board) with the following outcomes: 
- Joint Stock Companies are strongly involved in prevention of COVID-19 (increased expenses on testing at the employer's expense or reimbursement of nutritional supplements) than Limited Liability Companies;

- also, stronger emphasis on prevention place companies with exclusively woman in their board, unlike companies with mostly men in it;

- companies' resident in Bratislava region places stronger emphasis on helping the public and the local community with the COVID-19 related situation (sponsorship, participation in testing, vaccine research, etc.) than companies' resident in Nitra region;

- companies established between 1996-2000 place stronger emphasis on extra employee benefits related with elimination of COVID-19 incidence (e.g.: possibility to complete voluntary quarantine with income compensation) than companies established between 2001-2005.

- companies with foreign capital in their ownership structure place stronger emphasis on equipping employees with protective aids (drape, gloves, respirator etc.) in regard of elimination of COVID-19 incidence that companies owned exclusively by Slovakians.

We believe that our study laid the foundations of the examining of corporate social responsibility as a tool to eliminate the effects of the COVID-19 pandemic on business entities not only in Slovakia or in transforming economies. The scope did not allow us to address all aspects of this issue exhaustively. However, our outcomes are of high value for research and managers of Slovak companies since it can help them to identify notable features of company's social responsibility in elimination of COVID-19 impact and incidence. Also, our outcomes are actual and should be incorporated in teaching practice of future managers.

\section{Acknowledgement}

Paper was prepared within the project "Theory and Practice of International Management and Business in Multicultural Environment" no. 005SPU-4/2019 supported by KEGA Agency of The Ministry of Education. Science. Research and Sport of the Slovak Republic

\section{References}

1. Bae, K. H., El Ghoul. S., Gong. Z. J., \& Guedhami. O. (2021). Does CSR matter in times of crisis? Evidence from the COVID-19 pandemic. Journal of Corporate Finance, 67, 101876.

2. Beck, M. J., \& Hensher, D. A. (2021). Australia 6 months After COVID-19 Restrictions Part 2: The Impact of Working from Home. Transport Policy. In Press.

3. Čarnogurský, K., Diačiková, A., Ďaňková, A., \& Lach. M. (2015). Practical importance of CSR in cross-sector cooperation. Procedia Economics and Finance. 34, 244-251.

4. EC. (2006). Communication from the Commission to the European Parliament the Council and the European Economic and Social Committee - Implementing the partnership for growth and jobs making Europe a pole of excellence on corporate social responsibility. COM/2006/0136 final. https://eur-lex.europa.eu/LexUriServ.do?uri=COM:2006:0136:FIN:EN:PDF

5. Filatotchev, I., \& Stahl, G. K. (2015). Towards transnational CSR. Corporate social responsibility approaches and governance solutions for multinational corporations. Organizational Dynamics. 44(2), 121-129.

6. Gillham, B. (2000). Research interview. A\&C Black. New York. British Library.

7. Kim, J., \& Shin, W. (2014). How to do random allocation (randomization). Clinics in orthopedic surgery. 6(1), 103-109.

8. Kim, S., \& Ji, Y. (2021). Positive ripple effects of corporate leaders' CSR donations amid COVID19 on corporate and country reputations: Multi-level reputational benefits of CSR focusing on Bill Gates and Jack Ma. Public Relations Review. 47(4), 102073. 
9. Kruskal, W. H., \& Wallis, W. A. (1952). Use of ranks in one-criterion variance analysis. Journal of the American statistical Association. 47(260). 583-621.

10. Lee, S., \& Lee, D. K. (2018). What is the proper way to apply the multiple comparison test? Korean journal of anesthesiology. 71(5), 353.

11. Liou, R. S., Lamb, N. H., \& Lee. K. (2021). Cultural imprints: Emerging market multinationals' post-acquisition corporate social performance. Journal of Business Research. 126, 187-196.

12. Low, M. P. (2016). Corporate social responsibility and the evolution of internal corporate social responsibility in 21st century. Asian Journal of Social Sciences and Management Studies. 3(1), 56-74.

13. Margherita. A., \& HeikkilÄ. M. (2021). Business Continuity in the COVID-19 Emergency: A Framework of Actions Undertaken by World-Leading Companies. Business horizons, 64(5), 683695.

14. Meyer, B. H., Prescott, B., \& Sheng, X. S. (2021). The impact of the COVID-19 pandemic on business expectations. International Journal of Forecasting. In Press.

15. Mladenović, S. S., Mladenović, I., Milovančević, M., \& Denić, N. (2017). Cross-cultural dimensions influence on business internationalization by soft computing technique. Computers in Human Behavior. 75, 865-869.

16. Mulugeta, T. Tadesse, E., Shegute, T., \& Desta, T. T. (2021). COVID-19: socio-economic impacts and challenges in the working group. Heliyon, 7(6), e07307.

17. Nalband, N. A., \& Kelabi, S. A. (2014). Redesigning Carroll's CSR pyramid model. Journal of Advanced Management Science, 2(3).

18. Popkova, E., DeLo. P., \& Sergi, B. S. (2021). Corporate social responsibility amid social distancing during the COVID-19 crisis: BRICS vs. OECD countries. Research in International Business and Finance. 55, 101315.

19. Qiu, S. C., Jiang, J., Liu, X., Chen, M. H., \& Yuan, X. (2021). Can corporate social responsibility protect firm value during the COVID-19 pandemic? International Journal of Hospitality Management, 93, 102759.

20. Rayhan, R. U., Zheng, Y., Uddin, E., Timbol, Ch., Adewuyi, O., \& Baraniuk, J. N. (2013). Administer and collect medical questionnaires with Google documents: a simple safe and free system. Applied medical informatics, 33(3), 12-21.

21. Shapiro, S. S., \& Francia, R. S. (1972). An approximate analysis of variance test for normality. Journal of the American statistical Association, 67(337). 215-216.

22. Shin, H., Sharma, A., Nicolau, J. L., \& Kang, J. (2021). The impact of hotel CSR for strategic philanthropy on booking behavior and hotel performance during the COVID-19 pandemic. Tourism Managemen, 85, 104322.

23. Slaper, T. F., \& Hall, T. J. (2011). The triple bottom line: What is it and how does it work. Indiana business review, 86(1), 4-8.

24. Wapstra, A. H., Audi, G., \& Thibault, C. (2003). The Ame2003 atomic mass evaluation:(I). Evaluation of input data. adjustment procedures. Nuclear physics A, 729(1), 129-336.

25. Watson, G. S., \& Durbin, J. (1951). Exact tests of serial correlation using noncircular statistics. The Annals of Mathematical Statistics, 22(3), 446-451. 